\title{
Impact of HIV/AIDS mortality on South Africa's life expectancy and implications for the elderly population
}

\author{
Chuks J. Mba \\ Regional Institute for Population Studies, University of Ghana, Legon, Ghana (Email: chuksmba@ug.edu.gh; \\ Phone: 233-21-500274).
}

\begin{abstract}
SUMMARY
The study seeks to raise awareness and expand knowledge about the deleterious effect of HIV/AIDS mortality on South Africa's life expectancy, a country with a relatively high HIV/AIDS prevalence rate (19. percent). Using the multiple and associated single decrement life table techniques, the study estimates the total number of South Africans who would die from HIV/AIDS by the time they reach age 75 from a hypothetical cohort of 100,000 live births, assuming that the mortality conditions of 1996 for South Africa prevailed. The findings indicate that 5.7 percent of babies will eventually die of HIV/AIDS. Furthermore, 7.7 percent and 11.5 percent of those aged 60 years, and 75 years and above respectively will die of HIV/AIDS. Overwhelming majority of deaths will come from persons within the reproductive and productive age groups. A tremendous gain in life expectancy to the tune of about 26 years would result in the absence of HIV/AIDS. The elderly persons, who are the grandmothers and grandfathers, are likely to manage family affairs following the death of their adult children. This condition is likely to impoverish the elderly population. Everything should be done to reduce HIV/AIDS mortality in order to increase life expectancy in the country.
\end{abstract}

[Afr J Health Sci. 2007; 14:201-211]

\section{Introduction}

The acquired immune deficiency syndrome (AIDS) is caused by the human immunodeficiency virus (HIV). Infection with the virus leads to the destruction of a person's immune system, making the victim highly susceptible to multiple infections and ultimately results in the inevitable death of the victim since there is no cure for AIDS [1-4]. As at the end of 2006, 39.5 million people were living with HIV/AIDS, including 2.3 million children younger than 15 years [5]. About 5 young people aged 15-24 years become infected with HIV every minute. Available evidence indicates that about 21 million people have died from AIDS, and that about 95 percent of worldwide AIDS cases occur in developing countries, with nearly 70 percent of all cases occurring in sub-Saharan Africa [1-6]. The alarming and saddening consequences of this catastrophe are many and varied, one of which is the rapidly increasing number of both orphaned children and grandparenting since Africa is currently home to 70 percent of the world's AIDS orphans [7].

Research advances, funded through extraordinary investment in biomedical research, have resulted in effective treatments and a striking decrease in AIDS-related death rate in most developed countries. However, the toll in suffering and death in developing nations remains enormous and overshadows the epidemic in the developed world. Everyday, 14,500 people become infected; most of them in the developing countries; and in some African countries, between 25 and 35 percent of the adult population are infected [1,2]. The life expectancy in several African countries has decreased dramatically and has negated gains made during the past few decades on the pandemic. South Africa has one of the highest rates of the HIV/AIDS disease in the world. Available evidence suggests that 19.0 percent of the adult population in South Africa is living with the virus $[5,8]$.

The latest data show a continuing rising trend nationally in HIV infection levels among pregnant women attending public antenatal clinics: from 22.4 percent in 1999 to 30.2 percent in 2005, representing an increase of 35 percent [8]. A large proportion of the rising trend in death rates is attributable to AIDS epidemic. The disease continues to spread at an alarming rate. About 1,500 new infections are reported everyday, and the virus is most prevalent among young people in the prime of life. The high rate of the HIV/AIDS is already placing a strain on the social welfare system, a burden that is likely to increase dramatically in the next few years. 
Against this background, it is important to raise awareness and expanding knowledge about the deleterious effect of HIV/AIDS on South Africa's life expectancy for possible policy interventions. The country is selected as it lies at an extreme part of the HIV/AIDS spectrum, so that analyzing its HIV/AIDS profile will undoubtedly reveal the devastating impact of the pandemic. The effect of HIV/AIDS is felt by all population subgroups. However, some population subgroups, such as the elderly persons, are more vulnerable as they are left alone to take care of their grandchildren following the death of their children through AIDS.

In an attempt to achieve this objective, a stochastic procedure will be adopted whereby the life expectancy of the South African society will be simulated in the absence of HIV/AIDS.

Thus, the thrust of this study is to attempt to answer three basic questions. First, what is the contribution of HIV/AIDS mortality to the overall mortality of South Africa? Secondly, to what extent will life expectancy be enhanced if HIV/AIDS were absent in the mortality experience of the country? Thirdly, what are the consequences of the HIV/AIDS pandemic for the elderly persons?

\section{Materials and Methods}

The data for the present study emanate from the 1996 Census data file of South Africa, and the World Health Organization [3] database. It should be stated that the census data set of South Africa is part of the collection of census micro-data presently archived by the African Census Analysis Project of the Population Studies Center of the University of Pennsylvania, which are used for demographic research and training [9]. The 1996 census data were available for public use as at the time of this study.

The online version of the 1997-1999 World Health Statistics Annual [3] contains all data that have been received by the world body since the publication of the 1996 edition. The available data are official national statistics since they have been transmitted to the World Health Organization by the appropriate and competent government agencies of the various countries, including South Africa Annual [3]. Unfortunately, the actual number of AIDS cases is not known because of under-diagnosis, incomplete reporting and reporting delays not only in South Africa but also in other parts of Africa [3, 4, 10, 11, 12]. However, a technical report of the Medical Research Council of South Africa on the impact of HIV/AIDS estimated that AIDS deaths in South Africa accounted for about 14 percent of all deaths by 1996 [10]. The present study employs this information on the assumption that it furnishes a credible evidence of the HIV/AIDS mortality experience of the South African society. Then, postulating that the age structure of the HIV/AIDS mortality provided by the World Health Organization is relevant, the proportion of deaths due to HIV/AIDS for each age group can then be estimated by applying the 14 percent to the age structure to the World Health statistics that specifies causes of death for various age groups for each country [3].

It should be noted that the data provided by the World Health Organization from age 5 to age 74 are in broad 10-year age groups [3]. Therefore, the Karup-King interpolation multipliers are employed to break them into 5-year age groups $[12,13]$. Results of this computation are shown in the ${ }_{n} D_{x}^{i}$ columns.

In an attempt to determine the effect of death due to HIV/AIDS on the overall mortality experience of South Africa, the present study employs the multiple decrement life table techniques [14, 15 16, 17]. The multiple decrement procedures are based on the principle of competing risk; that is, as human beings are exposed to the risk of dying, death could result from various causes. The basic assumption underlying this principle is that the various causes of death are mutually exclusive and exhaustive $[14,18,19]$. The assumption of independence implies that the force of the mortality function from different causes is additive. In the specific context of South Africa, the state of interest is being alive and decrements from that state are attributable to HIV/AIDS and all other causes of death. Drawing from the conventional life table technique, the force of decrement from all causes combined is the sum of the force of decrement from HIV/AIDS and the force of decrement from all other causes. That is:

$\mu(x)=\mu^{1}(x)+\mu^{2}(x)+\ldots+\mu^{k}(x)$.

Thus, the force of decrement from cause $i$ at age $x$ is simply the rate at which persons are leaving the defined state from cause $i$.

Because it is not possible in real life situations to observe directly associated single decrement processes, that is, processes in which one decrement alone is operating, certain functions defined for the basic life table can be extended to the associated single decrement life table. Associated with each decrement $i$ in a multiple decrement process is a force of decrement function, $\mu^{i}(x)$. In general, the rate of decrement from $\mu^{i}(x)$ if $i$ were the only decrement differs from what it would be if $i$ were working in the presence of other decrements. The interest here is to determine the resultant life table, called the associated single decrement life table, if only the HIV/AIDS $(i)$ of decrement were 
operating to reduce the populations of South Africa. The decrement of interest is simply all decrements other than $i$ (that is, $-i$ ). Thus, the task is to construct a table based on $\mu^{-i}(x)$ in which cause $i$ will be arbitrarily deleted from the set of multiple decrements.

It should be stated that in the ensuing analysis, the estimation of life table functions, such as ${ }_{n} a_{x},{ }_{n} q_{x},{ }_{n} d_{x},{ }_{n} L_{x}$, and so on, follows the usual conventional approach. However, the calculation of the mean number of person-years lived in the interval by those dying in the interval, ${ }_{n} a_{x}$, is based on Chiang's (17) approach for ages above age 4, while for children below age 5, the procedure suggested by Coale and Demeny is adopted [20]. The probability of dying from the HIV/AIDS, ${ }_{n} \mathrm{q}_{\mathrm{x}}^{\mathrm{i}}$, is computed by applying the proportion of deaths that are due to the HIV/AIDS to the overall probability of dying between ages $\mathrm{x}$ and $\mathrm{x}+\mathrm{n},{ }_{\mathrm{n}} \mathrm{q}_{\mathrm{x}}$, as indicated hereunder:

${ }_{n} q_{x}^{i}={ }_{n} q_{x} \frac{{ }_{n} D_{x}{ }^{i}}{D_{x}}$

where ${ }_{n} \mathrm{D}_{\mathrm{x}}^{\mathrm{i}}$ is the observed total number of deaths from HIV/AIDS between ages $x$ and $x+n$, and ${ }_{n} \mathrm{D}_{\mathrm{x}}$ is the observed total number of deaths from all causes between ages $x$ and $x+n$.

In constructing the associated single decrement life table, the constant of proportionality for decrement other than HIV/AIDS in the interval $x$ to $x+n, R^{-i}$, is computed using the formula:

$R^{-i}=\frac{{ }_{n} D_{x}-{ }_{n} D_{x}^{i}}{{ }_{n} D_{x}}$

Also, the probability of surviving from age $x$ to age $x+n$ in the absence of HIV/AIDS, ${ }_{n} p_{x}^{-i}$, is estimated using the following formula proposed by Chiang [17]:

${ }_{n} p_{x}^{-i}=\left[{ }_{n} p_{x}\right]^{R^{-i}}$

while the average person-years lived between ages $x$ and $x+n$ in the absence HIV/AIDS, ${ }_{n} a_{x}^{-i}$, is calculated using the formula:

${ }_{n} a_{x}^{-i}=n+R^{-i} \frac{{ }_{n} q_{x}}{{ }_{n} q_{x}^{-i}}\left({ }_{n} a_{x}-n\right)$

for $x=0,1,5$ (ages under 10 years) and 70 (70-74 age group); but for the intervening age groups, $(x=10$ to $65)$, this formula is employed:
${ }_{5} a_{x}^{-i}=\frac{-\frac{5}{24}{ }_{5} d_{x-5}^{-i}+2.5_{5} d_{x}^{-i}+\frac{5}{24}{ }_{5} d_{x+5}^{-i}}{{ }_{5} d_{x}^{-i}}$.

However, it should be emphasized that vital registration system in South Africa is not complete implying that death registration coverage is not complete [10]. Consequently, caution should be exercised while interpreting the results of subsequent analysis.

\section{Results}

Table 1 shows the multiple decrement life table of South Africa in 1996 constructed with a view to finding out the contribution of HIV/AIDS to the overall mortality experience of the country. The findings reveal that the infant mortality rate and under five mortality rate are respectively about 23 deaths per 1,000 live births, and 25 deaths per 1,000 live births in South Africa. The graphical representation of the age-specific death rates, presented in Figure 1 indicates that mortality is high at very young ages, but declines to very low levels before age 25 , and rises gradually up to age 65 , and then much more rapidly thereafter in the country. The mortality estimates translate into expectations of life at birth of 63.6 years. These findings are consistent with mortality estimates for South Africa from other sources $[3,21,22,23,24,25]$.

Table 1 further shows that the proportion of new born babies that will eventually die from HIV/AIDS under the South Africa's age-causespecific death rates of 1996 is $5660 / 100,000=5.7$ percent. Furthermore, 7.7 percent and 11.5 percent of South Africans who survive to age 60 years, and 75 years and above respectively will die of HIV/AIDS under the prevailing age-specific mortality conditions $^{1}$. A striking feature of Figures 1 is that there is a noticeable improvement in age-specific death rates at all ages, especially after age 15 , when HIV/AIDS is eliminated in the country.

Table 2 indicates the associated single decrement life table for South Africa under a hypothetical scenario whereby HIV/AIDS is deleted to determine the extent of the resultant gain in expectation of life. The findings depicted in Table 2 show that the probability of surviving to age 75 in the absence of HIV/AIDS is $0.53(53454 / 100000)$, which is higher than $0.48(48471 / 100000)$, the probability of surviving to age 75 for all causes combined.

\footnotetext{
${ }^{1}$ That is, $(5595 / 72564) * 100=7.7$ percent; $(5580 / 48471)^{*} 100=11.5$ percent.
} 
This translates into a gain in life expectancy at birth of 26 years, from 63.6 years for all causes combined to 89.8 years in the absence of HIV/AIDS. These results show that there is a significant improvement in the mortality profile of the country less HIV/AIDS disease.

This tremendous gain in both the number of persons surviving to each age and expectation of life is better illustrated pictorially in Figures 2 and 3 . Figure 2 reveals that the number of survivors increased consistently from age 15 in the absence of HIV/AIDS. More remarkable are the results displayed in Figure 3. The graph indicates that there is a pronounced gain in life expectancy at every age with the deletion of HIV/AIDS. Consequently, the findings indicate that South Africa's life expectancy in will fare tremendously better if the HIV/AIDS scourge is eliminated or drastically reduced.

\section{Discussion}

Employing the multiple and associated single decrement life table techniques, the present study has attempted to estimate the total number of South Africans who would eventually die from HIV/AIDS by the time they reach age 75 from a hypothetical cohort of 100,000 live births, on the assumption that the mortality conditions of 1996 prevailed. The results of the analysis revealed that if the prevailing mortality conditions continued throughout their life span, about 11.5 percent of the population of South Africa might eventually die from HIV/AIDS by the time they attain age 75 or over. This is very high, as demonstrated also by a tremendous gain in life expectancy to the tune of about 26 years that would result in the absence of HIV/AIDS. In other words, the prevalence of HIV/AIDS reduces remarkably the expectation of life of the people. This fact is buttressed by a number of other studies $[2,3,4,10]$. In fact, the life expectancy in South Africa and several African countries has decreased dramatically and has negated gains made during the past few decades on the pandemic. The ultimate fate of persons with HIV is well known since virtually without exception, within 10 years of contracting the virus, the individuals develop fullblown AIDS and die. But before the symptoms of AIDS develop, persons living with HIV infection face ostracism, poverty, physical pain, and fear of impending death. Unfortunately, some people are unconcerned about HIV because of its long incubation period. Studies have shown that in the calculus of everyday life, the slow plague is a low priority for many, and they excuse their nonchalant attitude by arguing that by the time one dies of AIDS, one could well have died from other things many times over. [26, 27] The African authorities are faced with a number of stumbling blocks in dealing with the HIV/AIDS epidemic. The most notable problem lies with the highest risk group, the youth. Although government health and social welfare departments have opened major campaigns, distributing free condoms at schools, universities, and to the public, yet statistics continue to show an increase in infections, underscoring the ineffectiveness of the campaign. The fact remains that unbridled and promiscuous sexual behaviour among the youth contributes to the rapid spread of the virus. Among adults, the largest proportion of persons with HIV/AIDS has contracted the disease through multiple heterosexual partners $[28,29,30]^{2}$. Therefore, the disease will be effectively contained if a determined effort targets the youth with an abstinence approach. In fact, it is widely believed that sexual abstinence programmes, which emphasize abstaining from sex, are a person's best choice and the only sure way of preventing pregnancy and HIV/AIDS and other diseases [31].

Another obstacle to HIV/AIDS education among young people is apathy, couple with ignorance. The attitude of some that "AIDS will not affect me" possibly stems from the nature of the disease. This is because in its early stages, an infected person lives a normal, apparently healthy life. On the other hand, admitting to having contracted a sexually transmitted infection, especially the HIV disease, is generally a source of great embarrassment for people in most cultures [32, 33, 34, 35]. Another factor placing an ever-increasing number of women, especially teenagers and young adults, in danger of contracting the disease is the high incidence of rape in South Africa. Every 25 seconds, a woman or child is raped in the country hereby exposing the victims to the danger of HIV/AIDS infection [36, 37]. The government of South Africa could benefit from Thailand's experience. This is because Thailand was one of the countries worst hit by HIV/AIDS in the 1980s. However, the country's most significant strategy in its AIDS prevention programme is its policy of 100 percent condom use in sex establishments.

\footnotetext{
${ }^{2}$ These findings should be accepted because even though more recent studies argue that about 60 percent of HIV/AIDS infections are contracted through medical lapses, such as use of unsterilised syringes, one syringe for more than one person, and contaminated blood transfusion, they have not yet been internationally peer-reviewed and validated.
} 


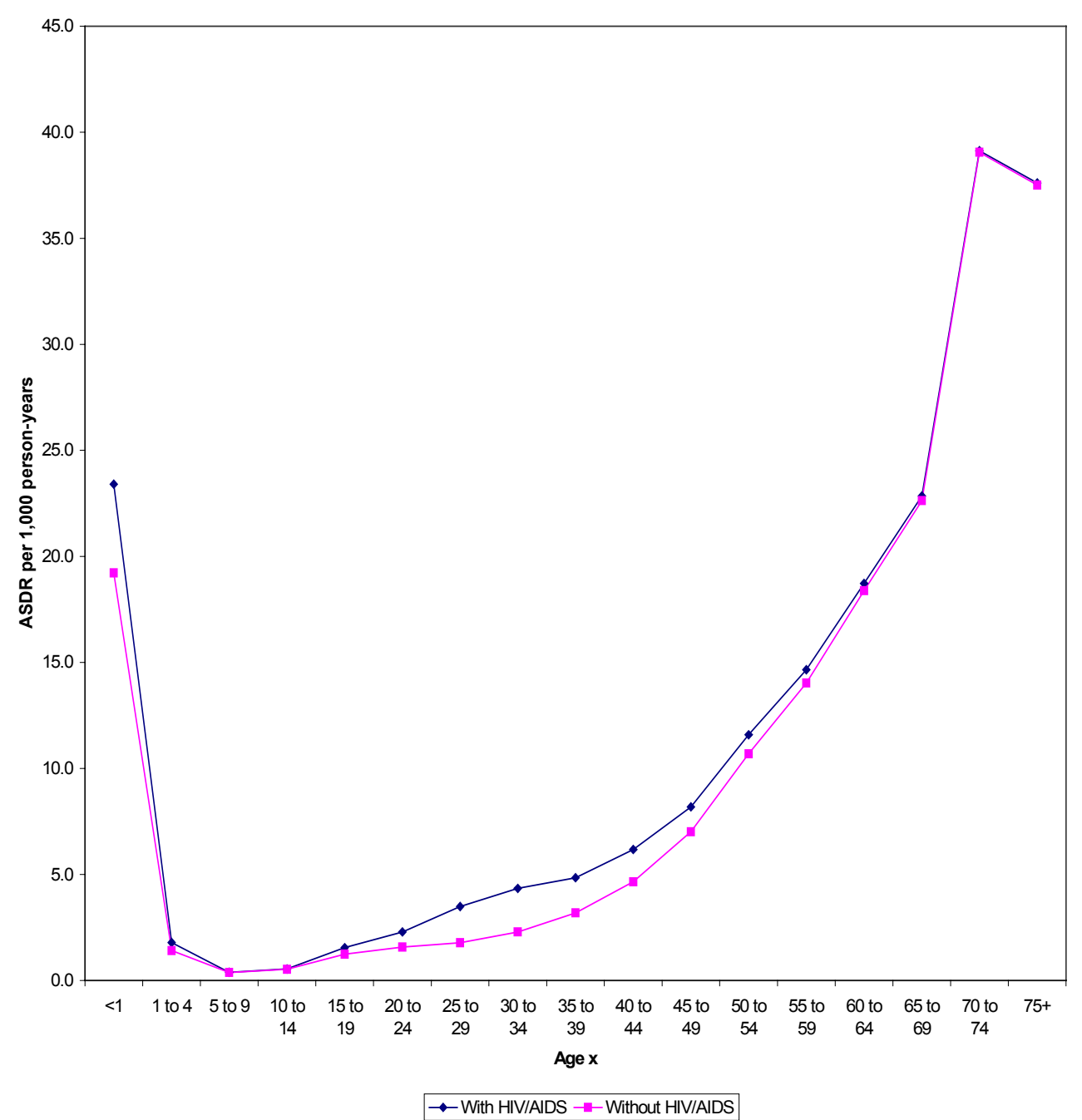

The policy, adopted in 1991, prevents customers from purchasing sexual services unless they use condoms. As a result, the incidence of STDs has dropped from more than 400,000 cases per year before 1991 to fewer than 14,000 cases per year since 2000 [38.] Parents and other family members in Africa are in a unique position to help socialize adolescents into healthy sexual adults, both by providing accurate information about sex and by fostering responsible sexual decision-making skills. This is because some studies have found that family discussions about sex are related to higher levels of knowledge about sexuality and AIDS among adolescents, as well as a lower incidence of sexual risk-taking behaviour [39, 40]. Moreover, adolescents and children often cite their parents as their preferred source of education about sex, and organized prevention and education efforts continue to advocate active parental involvement in children's sexual socialization, especially in industrialized countries $[41,42]$.
Unlike many other endemic diseases, AIDS is not 'sensitive' to the socioeconomic status of anybody and thus does not spare the elite. As a result, levels of HIV prevalence among high-income, urban, and relatively well-educated men and women are as high as those among low-income and rural groups, if not higher. Because wealthier, more-skilled, and bettereducated subsets of the population have higher levels of consumption and investment, command higher wages, and are more likely to be employers, any disease affecting this group relatively more than other groups is likely to have a greater economic impact per case.

Although gerontology is still in its infancy in much of Africa, the ageing process is gradually gaining momentum in South Africa as evidenced by the appreciation of the social benefits and problems associated with this process, as well as research [26, $43,44,45,46]$. It is highly commendable that South Africa is one of the very few African countries where economic support for the elderly exists. 
Fig 2: Number of Survivors at Age x (Ix), 1996 (South Africa)

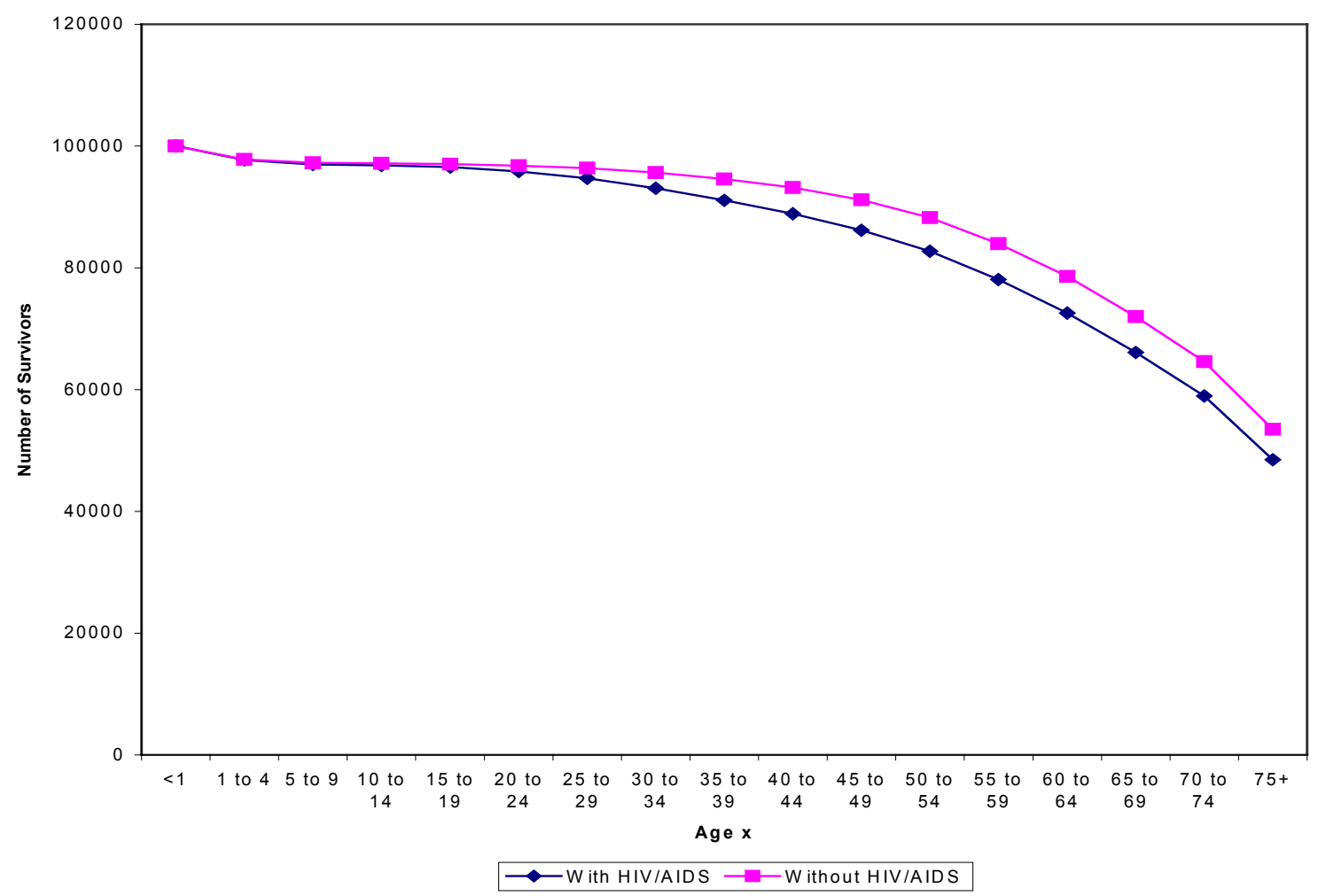

All women aged 60 or more and men aged 65 or more are eligible for a social pension of about $\$ 100$ per month [26, 47, 48]. However, an increase in the number of the elderly in a context of a health crisis due to the HIV/AIDS pandemic constitutes a real challenge. As full-blown AIDS is fatal, sociologically the survivors feel the main impact. Although the survivors are considered as secondary victims, it is the survivors upon whom the full weight of sustaining a decimated, confused and demoralised community falls. The elderly persons, who are the grandmothers and grandfathers, are likely to be the most active persons to manage the family affairs in the event of the death of their adult children. This condition is likely to impoverish the elderly population. Adults aged 15-49 years are usually the economic backbone of their families and their communities, on whom both young children and elderly parents rely for care and support. The implication of the prevalence of HIV/AIDS in South Africa is that there would be a noticeably fewer number of adults in their economically productive ages in the country due to the ravages of the HIV/AIDS pandemic. This is likely to undermine economic progress and pose enormous challenges to the government. This fact is buttressed by the projected labour force participation with AIDS and losses due to HIV/AIDS for the period 2005-2020 [49]. For example, the evidence indicates that the size of the labour force will be 25 percent smaller in South Africa by the year 2020 as compared to situation without HIV/AIDS. Unfortunately, many of those infected with HIV are experienced and skilled workers in both white-collar and blue-collar jobs. The ING Barings Bank [50] has projected that onethird of the semi-skilled and unskilled workforce will be HIV-positive by 2005, while 23 percent of the skilled and 13 percent of the highly skilled workforce will be HIV-positive over the same period in South Africa. It logically follows that the illness and death of these economically active prime-age adults will inevitably result not only in lower incomes for surviving elderly family members, but also in all the other sequelae of poverty, including worsened health and reduced investment in the survivors' future productivity. Secondly, the fatality of AIDS and the duration of the illness increase its impact per case relative to other causes of morbidity [51]. The long incubation period of HIV implies that the economic impact of existing levels of infection will be felt for upwards of 10 years, even if all infections were to cease today. Early deaths due to AIDS are generating large numbers of people, particularly the elderly, who are at increased risk of poverty. 
Fig 3: Life Expectancy at Age x, 1996 (South Africa)

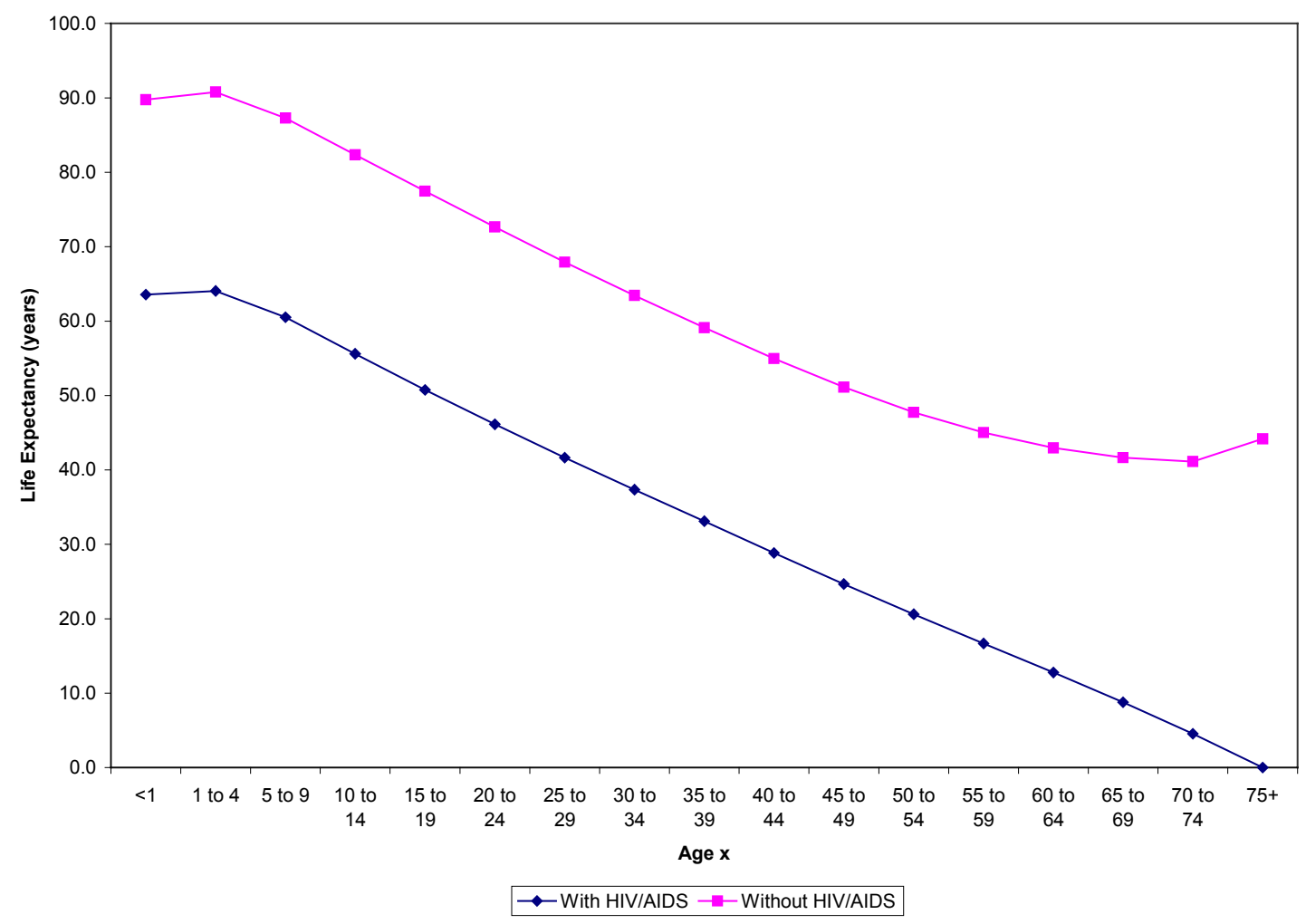

A death in the household as a result of AIDS can have profound implications for resource allocation, production, consumption, savings, investment and the well-being of survivors [52]. Thus, AIDS has an unusually devastating effect on the entire household, both through loss of income and through dissolution of normal social relationships within the family setup. Because deterioration from AIDS is such a slow process, many families exhaust their entire savings before the person with AIDS finally dies. Furthermore, families lose income not only from the infected person, but also from other family members involved in his or her care. This loss is especially acute for families with more than one infected person. It is obvious that the pendulum of this crisis swings disproportionately against the elderly family members.

These policy implications need to be considered in the light of the study's limitations, however. In the first instance, as stated previously, vital registration system is still incomplete in South Africa. As a result, not all deaths and their causes are recorded. Secondly, the observed data used are crosssectional; thus, implications about causality cannot be drawn. Additionally, the data came from various sources and from differing time periods. As a result, comparison is questionable.

\section{Conclusion}

Future research might build on the findings of this study by focusing on how the process of sexual communication relates to sexual risk-taking behaviour. Sample surveys should investigate the role of parents, addressing what they say, as well as their attitudes toward adolescent sexuality and their own behaviour that they present as a model for their adolescent children. To understand, and perhaps change, how parents influence adolescent sexuality, the complex set of behaviours and attitudes that constitute parenting should be studied further.

\section{References}

1. United Nations. World Population Prospects, The 2004 Revision Vol. I: Comprehensive Tables. Department of Economic and Social Affairs, Population Division, ST/ESA/SER.A/244. New York. 2005; 265p.

2. United Nations. World Population Prospects, The 2000 Revision: Highlights. 
Population Division, Department of Economic and Social Affairs, ESA/P/WP.165, New York. 2001; 167pp.

3. World Health Organization. 1997-1999 World Health Statistics Annual. http://www3.who.int/whosis/. The WHO, Geneva, Switzerland. 2001, p78-89.

4. UNAIDS. Report on the Global HIV/AIDS Epidemic, June 2000. Joint United Nations Programme on HIV/AIDS, Geneva, Switzerland. 2000; p43.

5. UNAIDS/WHO. AIDS Epidemic Update: December 2006. The UNAIDS, Geneva, Switzerland. 2006. http://data.unaids.org/pub/EpiReport/2006/2 006 EpiUpdate en.pdf

6. United Nations. World Population Prospects, The 2000 Revision Vol. I: Comprehensive Tables. Department of Economic and Social Affairs, Population Division, ST/ESA/SER.A/198. New York. 2001; p.22.

7. Phiri R. Africa is home to $70 \%$ of World's HIV/AIDS Orphans. The Post, November 16, 2001. Lusaka, Zambia.

8. Department of Health South Africa. Summary of Biennial Report on the State of the South African HIV/AIDS Epidemic. Department of Health South Africa. 2006; $26 \mathrm{p}$.

9. Zuberi T. Introduction, in African Censuses in the $21^{\text {st }}$ Century. Fourth African Census Analysis Project Workshop. Social Change and the Demography of Africa: Evidence from the Analysis of Census Data. Dakar, Senegal, January 15-17.2001; p1-4

10. Dorrington R, Bourne D, Bradshaw D, Laubscher $\mathrm{R}$ and Timaeus, I. The Impact of HIV/AIDS on Adult Mortality in South Africa. Technical Report, Burden of Disease Research Unit, Medical Research Council, South Africa. 2001; p45-59.

11. Zimbabwe Ministry of Health. HIV, STD and AIDS Surveillance. Zimbabwe Quartely Reports. No 3.

12. Siegel JS and Swanson DA. (eds.) The Methods and Materials of Demography. Second Edition. Washington, D.C., U.S. Census Bureau. 2004; 850p

13. Preston SH, HeuvelineP, and Guillot $\mathrm{M}$. Demography: Measuring and Modeling Population Processes. New York: Academic Press. 2000; 221p

14. Namboodiri K and Suchindran CM. Life Table Techniques and Their Applications. Academic Press Inc., London. 1987; 275p
15. Keyfitz N. Applied Mathematical Demography. Springer Texts in Statistics, Springer-Verlag, New York. 1985 441p

16. Chiang CL. Introduction to Stochastic Processs in Biostatistics. Wiley Publishers, New York. 1968; 201p

17. Namboodiri K. Demographic Analysis: A Stochastic Approach. Academic Press Inc., London. 1991; 370p

18. Chhiang CL. The Life Table and Its Applications. Robert E. Krieger Publishing Company, Malabar, Frorida. 1984; 336p

19. Coale A and Demeny P. Regional Model Life Tables and Stable Populations. Academic Press, New York. 1983; 496p

20. World Health Organization. World Mortality in 2000: Life Tables for 191 Countries. The WHO, Geneva, Switzerland. 2002; 223p

21. Udjo EO. A Four "Race" Model of Mortality in South Africa. Social Change and the Demography of Africa: Evidence from the Analysis of Census Data. Fourth African Census Analysis Project Workshop, Dakar, Senegal, January 15-17, pp.18-29, 2001.

22. World Bank. World Development Indicators database. The World Bank Group. 2000; $234 \mathrm{p}$.

23. Republic of South Africa. Statistics in Brief. Central Statistics. Steyn's Arcade, Pretoria, South Africa. 1997; 18pp.

24. Kinsella K. and Ferreira, M. Aging Trends: South Africa. U.S. Bureau of the Census and University of Cape Town, Cape Town. 1997; 178p.

25. Caldwell JC, Orubuloye IO and Caldwell P. Underreaction to AIDS in sub-Saharan Africa. In Orubuloye, IO., Caldwell JC., Caldwell P and Santow G. (eds.), Sexual Networking and AIDS in Sub-Saharan Africa: Behavioural Research and the Social Context. Health Transition Centre, Australian National University, Canberra, Australia. 1994; Pp.217-234.

26. Schoepf BG. Women, AIDS, and Economic Crisis in Central Africa. Canadian Journal of African Studies. 1988; 22:625-644.

27. Ministry of Health. HIV/AIDS in Ghana: Background, Projections, Impacts, Interventions, and Policy. National AIDS/STI Control Programme, Disease Control Unit, Ministry of Health, Accra. 2002; p23. 
28. Mbamaonyeukwu JC. The Battle Against HIV/AIDS: The Winds are Contrary, The Spectator, Saturday, March 24, 2001; p.3.

29. Mbamaonyeukwu JC. AIDS: A Threat to Humanity. The Spectator, Saturday, December 2, 2000; p3.

30. Associated Press. Sexual Abstinence Program Continued. Philadelphia Metro, Thursday, April 25, 2002; p2.

31. Awusabo-Asare K. and Anarfi JK. Healthseeking Behaviour of Persons with HIV/AIDS in Ghana. Health Transition Review. 1997; 7 Supple: 243-256.

32. Youn G. Sexual Activities and Attitudes of Adolescent Koreans. Archives of Sexual Behaviour. 1996; 25:629-643.

33. Danziger R. The Social Impact of HIV/AIDS in Developing Countries. Social Science and Medicine. 1994; 39: 905-917.

34. Over $M$ and Piot P. HIV Infection and Sexually Transmitted Diseases. In Jamison, DT. and Mosley H. (eds.), Disease Control Priorities in Developing Countries. Oxford University Press, New York. 1993; Pp.455527.

35. Boseley S, South Africa Doing Nothing to Halt AIDS/HIV Judge Says. The Guardian, Tuesday, July 11, 2000.

36. Spicer C. AIDS Spreads in South Africa. National Catholic Reporter. November 5 Issue, 1999; pp2-4.

37. Malaysian National News Agency (BERNAM), 2001. 100 Percent Condom Use Policy is Significant Strategy, says Thailand. November 5, 2001.

38. Pick S and Palos P. Impact of the Family on the Sex Lives of Adolescents. Adolescence, 1995; 30:667-675

39. Fisher TD. An Extension of the Findings of Moore, Peterson, and Furstenberg (1986) Regarding Family Sexual Communication and Adolescent Sexual Behavior. Journal of Marriage and the Family. 1989; 51:637639.

40. Bowler S, Sheon AR, D'Angelo LJ, Vermund SH. HIV and AIDS among Adolescents in the United States: Increasing Risk in the 1990s. Journal of Adolescence. 1992; 15:345-371.
41. Alexander SJ. Improving Sex Education Programs for Young Adolescents: Parents' Views. Family Relations. 1984; 33:251-257.

42. Chuks JM.. Racial Difference in marital status and living arrangements of older persons in South Africa. Generations review. Journal of British Society of Gerontology. 2005;15:23-31

43. Sagner A. Ageing and Social Policy in South Africa: Historical Perspectives with Particular Reference to the Eastern Cape. Journal of Southern African Studies. 2000; 26:523-553.

44. U.S. Bureau of the Census. Population Aging in Southern Africa. Center for International Research U.S. Bureau of the Census. 1994; 129p.

45. Ferreira M, Moller V, Prinsloo FR and Gillis LS. Multidimensional Survey of Elderly South Africans, 1990-1991: Key Findings. Monograph No. 1, Centre for Gerontology, University of Cape Town, Cape Town. 1992; 22p.

46. May J. Poverty and Inequality in South Africa, Summary Report, Praxis Publishing, Durban. 1998; 18p.

47. Ministry for Welfare and Population Development. White Paper for Social Welfare: Principles, Guidelines, Recommendations, Proposed Policies and Programmes for Developmental Social Welfare in South Africa.. Cape and Transvaal Printers, Cape Town. 1997, 32p.

48. International Labour Office (ILO). POPILO: Population and Labour Force Projection. The ILO, Geneva, Switzerland. 2000; 154p.

49. ING Barings Bank. The Economic Impact of AIDS in South Africa. South Africa. 1999; $78 \mathrm{p}$.

50. Ryder R, Batter V, Kaseka N, Behets F, Sequeira D, M'Boly E, Kanda M, Tshibambe $M$, and Morgan $M$. Effect of HIV-1 Infection on Tuberculosis and Fertility in a Large Workforce in Kinshasa, Democratic Republic of Congo. AIDS Patient Care \& STDS. 2000; 14: 297-304.

51. Ainsworth $M$ and Over M. AIDS and African Development. World Bank Research Observer. 1994; 9: 203-24. 
Table 1. Multiple Decrement Life Table of South Africa, 1996

\begin{tabular}{|c|c|c|c|c|c|c|c|c|c|c|c|c|c|c|c|c|}
\hline $\begin{array}{l}\mathrm{Ag} \\
\mathrm{e} x\end{array}$ & ${ }_{n} N_{x}$ & ${ }_{n} D_{x}$ & ${ }_{n} m_{x}$ & $\mathrm{n}_{\mathrm{x}}$ & ${ }_{n} q_{x}$ & ${ }_{n} p_{x}$ & $1_{x}$ & ${ }_{n} d_{x}$ & ${ }_{n} L_{x}$ & $\mathrm{~T}_{\mathrm{x}}$ & $\mathrm{e}_{x}^{o}$ & ${ }_{n} D_{x}^{i}$ & ${ }_{n} q_{x}^{i}$ & ${ }_{n} d_{x}^{i}$ & $1_{x}^{1}$ & ${ }_{n} \mathrm{~m}_{\mathrm{x}}^{\mathrm{i}}$ \\
\hline 0 & 856239 & 20045 & 0.0234 & 0.113 & 0.0229 & 0.9771 & 100000 & 2293 & 97966 & 6356769 & 63.6 & 3585 & 0.0041 & 410 & 5660 & 0.0042 \\
\hline 1 & 3587382 & 6431 & 0.0018 & 1.583 & 0.0071 & 0.9929 & 97707 & 698 & 389140 & 6258802 & 64.1 & 1374 & 0.0015 & 149 & 5655 & 0.0004 \\
\hline 5 & 4668722 & 1822 & 0.0004 & 2.233 & 0.0019 & 0.9981 & 97009 & 189 & 484522 & 5869663 & 60.5 & 34 & 0.0000 & 4 & 5650 & 0.0000 \\
\hline 10 & 4654100 & 2543 & 0.0005 & 2.309 & 0.0027 & 0.9973 & 96820 & 264 & 483389 & 5385141 & 55.6 & 67 & 0.0001 & 7 & 5645 & 0.0000 \\
\hline 15 & 4180716 & 6484 & 0.0016 & 2.430 & 0.0077 & 0.9923 & 96556 & 746 & 480862 & 4901752 & 50.8 & 1307 & 0.0016 & 150 & 5640 & 0.0003 \\
\hline 20 & 3982353 & 9116 & 0.0023 & 2.450 & 0.0114 & 0.9886 & 95810 & 1090 & 476270 & 4420890 & 46.1 & 2848 & 0.0036 & 341 & 5635 & 0.0007 \\
\hline 25 & 3455728 & 12058 & 0.0035 & 2.463 & 0.0173 & 0.9827 & 94720 & 1638 & 469443 & 3944621 & 41.6 & 5896 & 0.0085 & 801 & 5630 & 0.0017 \\
\hline 30 & 3074201 & 13368 & 0.0043 & 2.467 & 0.0215 & 0.9785 & 93082 & 2002 & 460338 & 3475178 & 37.3 & 6332 & 0.0102 & 948 & 5625 & 0.0021 \\
\hline 35 & 2653755 & 12857 & 0.0048 & 2.469 & 0.0239 & 0.9761 & 91080 & 2180 & 449882 & 3014839 & 33.1 & 4389 & 0.0082 & 744 & 5620 & 0.0017 \\
\hline 40 & 2138626 & 13211 & 0.0062 & 2.470 & 0.0304 & 0.9696 & 88900 & 2704 & 437663 & 2564957 & 28.9 & 3250 & 0.0075 & 665 & 5615 & 0.0015 \\
\hline 45 & 1677525 & 13739 & 0.0082 & 2.470 & 0.0401 & 0.9599 & 86197 & 3458 & 422236 & 2127294 & 24.7 & 1977 & 0.0058 & 498 & 5610 & 0.0012 \\
\hline 50 & 1268895 & 14705 & 0.0116 & 2.467 & 0.0563 & 0.9437 & 82739 & 4657 & 401895 & 1705059 & 20.6 & 1139 & 0.0044 & 361 & 5605 & 0.0009 \\
\hline 55 & 1069936 & 15682 & 0.0147 & 2.462 & 0.0707 & 0.9293 & 78081 & 5517 & 376406 & 1303163 & 16.7 & 670 & 0.0030 & 236 & 5600 & 0.0006 \\
\hline 60 & 890536 & 16675 & 0.0187 & 2.455 & 0.0894 & 0.9106 & 72564 & 6485 & 346320 & 926757 & 12.8 & 302 & 0.0016 & 117 & 5595 & 0.0003 \\
\hline 65 & 758887 & 17345 & 0.0229 & 2.448 & 0.1080 & 0.8920 & 66079 & 7135 & 312187 & 580437 & 8.8 & 168 & 0.0010 & 69 & 5590 & 0.0002 \\
\hline 70 & 482163 & 18866 & 0.0391 & 2.416 & 0.1777 & 0.8223 & 58944 & 10473 & 267658 & 268250 & 4.6 & 34 & 0.0003 & 19 & 5585 & 0.0001 \\
\hline 75 & 1183808 & 44531 & 0.0376 & 0.012 & 1.0000 & 0.0000 & 48471 & 48471 & 592 & 592 & 0.0 & 130 & 0.0029 & 142 & 5580 & 0.0001 \\
\hline
\end{tabular}

Sources: South Africa's 1996 Census (for ${ }_{n} \mathrm{~N}_{\mathrm{x}}$ values) and World Health Organization, 2001 (for ${ }_{n} \mathrm{D}_{\mathrm{x}}$ values).

Note: ${ }_{\mathrm{n}} \mathrm{N}_{\mathrm{x}}=$ Population size between ages $x$ and $x+n ;{ }_{\mathrm{n}} \mathrm{D}_{\mathrm{x}}=$ Total number of deaths between ages $x$ and $x+n$;

${ }_{n} \mathrm{~m}_{\mathrm{x}}=$ Observed age-specific death rates between ages $x$ and $x+n ;{ }_{\mathrm{n}} \mathrm{a}_{\mathrm{x}}=$ Average person-years lived between ages $x$ and $x+n$;

${ }_{n} q_{\mathrm{x}}=$ Probability of dying between ages $x$ and $x+n ;{ }_{n} \mathrm{p}_{\mathrm{x}}=$ Probability of surviving from age $x$ to age $x+n$;

$1_{\mathrm{x}}=$ Number of people left alive at age $x ;{ }_{\mathrm{n}} \mathrm{d}_{\mathrm{x}}=$ Number of people dying between ages $x$ and $x+n$;

${ }_{n} \mathrm{~L}_{\mathrm{x}}=$ Person-years lived between ages $x$ and $x+n ; \mathrm{T}_{\mathrm{x}}=$ Person-years lived above age $x$; $\mathrm{e}_{x}^{o}=$ Life Expectancy at age $x$;

${ }_{n} \mathrm{D}_{\mathrm{x}}^{\mathrm{i}}=$ Total number of deaths from HIV/AIDS between ages $x$ and $x+n ;{ }_{n} \mathrm{q}_{\mathrm{x}}^{\mathrm{i}}=$ Probability of dying from HIV/AIDS between ages $x$ and $x+n$;

${ }_{n} \mathrm{~d}_{\mathrm{x}}^{\mathrm{i}}=$ Number of people dying from HIV/AIDS between ages $x$ and $x+n ; 1_{\mathrm{x}}^{\mathrm{i}}=$ Number of people left alive from HIV/AIDS at age $x$;

${ }_{n} \mathrm{~m}_{\mathrm{x}}^{\mathrm{i}}=$ Observed age-specific death rates from HIV/AIDS between ages $x$ and $x+n$. 
Table 2. Associated Single Decrement Life Table for Causes of Death other than HIV/AIDS, South Africa, 1996.

\begin{tabular}{|c|c|c|c|c|c|c|c|c|c|c|c|c|c|c|c|}
\hline $\begin{array}{l}\mathrm{Ag} \\
\mathrm{e} x\end{array}$ & $R^{-i}$ & $1_{x}$ & ${ }_{n} p_{x}$ & $\mathrm{n}^{\mathrm{a}}$ & ${ }_{n} q_{x}$ & $\mathrm{e}_{x}^{o}$ & ${ }_{n} p_{x}^{-i}$ & ${ }_{n} q_{x}^{-i}$ & $l_{x}^{-i}$ & ${ }_{n} a_{x}^{-i}$ & ${ }_{n} d_{x}^{-i}$ & ${ }_{n} m_{x}^{-i}$ & ${ }_{n} L_{x}^{-i}$ & $T_{x}^{-i}$ & $e_{x}^{-i}$ \\
\hline 0 & 0.9620 & 100000 & 0.9771 & 0.113 & 0.0229 & 63.6 & 0.9779 & 0.0221 & 100000 & 0.114 & 2207 & 0.0225 & 98043 & 8975786 & 89.8 \\
\hline 1 & 0.7792 & 97707 & 0.9929 & 1.583 & 0.0071 & 64.1 & 0.9944 & 0.0056 & 97793 & 1.585 & 544 & 0.0014 & 389855 & 8877742 & 90.8 \\
\hline 5 & 0.4473 & 97009 & 0.9981 & 2.233 & 0.0019 & 60.5 & 0.9991 & 0.0009 & 97248 & 2.235 & 85 & 0.0002 & 486006 & 8487887 & 87.3 \\
\hline 10 & 0.4833 & 96820 & 0.9973 & 2.309 & 0.0027 & 55.6 & 0.9987 & 0.0013 & 97163 & 2.751 & 128 & 0.0003 & 485528 & 8001880 & 82.4 \\
\hline 15 & 0.3189 & 96556 & 0.9923 & 2.430 & 0.0077 & 50.8 & 0.9975 & 0.0025 & 97035 & 2.737 & 240 & 0.0005 & 484634 & 7516352 & 77.5 \\
\hline 20 & 0.3652 & 95810 & 0.9886 & 2.450 & 0.0114 & 46.1 & 0.9958 & 0.0042 & 96795 & 2.754 & 404 & 0.0008 & 483071 & 7031718 & 72.6 \\
\hline 25 & 0.4407 & 94720 & 0.9827 & 2.463 & 0.0173 & 41.6 & 0.9923 & 0.0077 & 96392 & 2.680 & 738 & 0.0015 & 480246 & 6548648 & 67.9 \\
\hline 30 & 0.5099 & 93082 & 0.9785 & 2.467 & 0.0215 & 37.3 & 0.9890 & 0.0110 & 95654 & 2.630 & 1055 & 0.0022 & 475768 & 6068401 & 63.4 \\
\hline 35 & 0.6227 & 91080 & 0.9761 & 2.469 & 0.0239 & 33.1 & 0.9850 & 0.0150 & 94599 & 2.639 & 1416 & 0.0030 & 469651 & 5592633 & 59.1 \\
\hline 40 & 0.7118 & 88900 & 0.9696 & 2.470 & 0.0304 & 28.9 & 0.9783 & 0.0217 & 93183 & 2.649 & 2026 & 0.0044 & 461152 & 5122982 & 55.0 \\
\hline 45 & 0.7919 & 86197 & 0.9599 & 2.470 & 0.0401 & 24.7 & 0.9681 & 0.0319 & 91157 & 2.657 & 2908 & 0.0065 & 448972 & 4661830 & 51.1 \\
\hline 50 & 0.8576 & 82739 & 0.9437 & 2.467 & 0.0563 & 20.6 & 0.9515 & 0.0485 & 88249 & 2.617 & 4278 & 0.0099 & 431051 & 4212858 & 47.7 \\
\hline 55 & 0.9052 & 78081 & 0.9293 & 2.462 & 0.0707 & 16.7 & 0.9358 & 0.0642 & 83971 & 2.587 & 5389 & 0.0133 & 406847 & 3781807 & 45.0 \\
\hline 60 & 0.9368 & 72564 & 0.9106 & 2.455 & 0.0894 & 12.8 & 0.9160 & 0.0840 & 78581 & 2.561 & 6598 & 0.0175 & 376817 & 3374960 & 42.9 \\
\hline 65 & 0.9508 & 66079 & 0.8920 & 2.448 & 0.1080 & 8.8 & 0.8971 & 0.1029 & 71984 & 2.624 & 7411 & 0.0217 & 342313 & 2998143 & 41.7 \\
\hline 70 & 0.9661 & 58944 & 0.8223 & 2.416 & 0.1777 & 4.6 & 0.8278 & 0.1722 & 64573 & 2.424 & 11119 & 0.0378 & 294223 & 2655830 & 41.1 \\
\hline 75 & 0.9814 & 48471 & 0.0000 & 0.012 & 1.0000 & 0.0 & 0.0000 & 1.0000 & 53454 & 0.012 & 53454 & 0.0369 & 2361606 & 2361606 & 44.2 \\
\hline
\end{tabular}

Sources: South Africa's 1996 Census (for ${ }_{n} \mathrm{~N}_{\mathrm{x}}$ values) and World Health Organization, 2001 (for ${ }_{\mathrm{n}} \mathrm{D}_{\mathrm{x}}$ values).

Note: $R^{-i}=$ Constant of proportionality for decrement other than HIV/AIDS in the interval $x$ to $x+n ; 1_{\mathrm{x}}=$ Number of people left alive at age $x$; ${ }_{\mathrm{n}} \mathrm{p}_{\mathrm{x}}=$ Probability of surviving from age $x$ to age $x+n ;{ }_{n} \mathrm{a}_{\mathrm{x}}=$ Average person-years lived between ages $x$ and $x+n$;

${ }_{n} \mathrm{q}_{\mathrm{x}}=$ Probability of dying between ages $x$ and $x+n ; \mathrm{e}_{x}^{o}=$ Life Expectancy at age $x ;{ }_{n} p_{x}^{-i}=$ Probability of surviving from age $x$ to age $x+n$ in the absence of HIV/AIDS; ${ }_{n} q_{x}^{-i}=$ Probability of dying between ages $x$ and $x+n$; deaths between ages $x$ and $x+n$ in the absence of HIV/AIDS;

$l_{x}^{-i}=$ Number of people left alive at age $x$ in the absence of HIV/AIDS; ${ }_{n} a_{x}^{-i}=$ Average person-years lived between ages $x$ and $x+n$ in the absence of HIV/AIDS; ${ }_{n} d_{x}^{-i}=$ Number of people dying between ages $x$ and $x+n$ in the absence of HIV/AIDS; ${ }_{n} m_{x}^{-i}=$ Observed age-specific death rates between ages $x$ and $x+n$ in the absence of HIV/AIDS; ${ }_{n} L_{x}^{-i}=$ Person-years lived between ages $x$ and $x+n$ in the absence of HIV/AIDS;

$T_{x}^{-i}=$ Person-years lived above age $x$ in the absence of HIV/AIDS; $e_{x}^{-i}=$ Life Expectancy at age $x$ in the absence of HIV/AIDS. 